College of William \& Mary Law School William \& Mary Law School Scholarship Repository

2009

\title{
Collaborative Governance: Lessons for Europe from U.S. Electricity Restructuring
}

Charles H. Koch Jr.

William \& Mary Law School

\section{Repository Citation}

Koch, Charles H. Jr., "Collaborative Governance: Lessons for Europe from U.S. Electricity Restructuring" (2009). Faculty Publications. 1270.

https://scholarship.law.wm.edu/facpubs/1270

Copyright c 2009 by the authors. This article is brought to you by the William \& Mary Law School Scholarship Repository. 


\title{
COLLABORATIVE GOVERNANCE: LESSONS FOR EUROPE FROM U.S. ELECTRICITY RESTRUCTURING
}

\author{
Charles H. KOCH, JR.*
}

\section{TABLE OF CONTENTS}

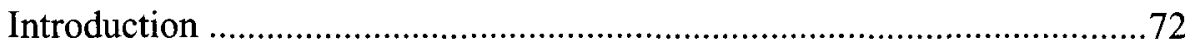

I. Shared Problem.................................................................... 73

II. Profile of the Electricity System ...................................................

III. Evolution of U.S. Electricity Policy ..................................................76

A. Major Shift in U.S. Regulatory Strategy ..................................76

B. The ISO/RTO Solution ..........................................................

C. Collaborative Governance Model in Electricity .........................79

IV. European Developments ...........................................................81

A. Treaty Recognition of Energy ..................................................82

B. Legislative Developments Toward a "Third Legislative

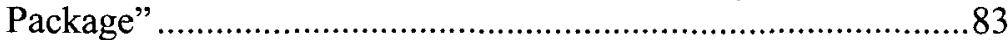

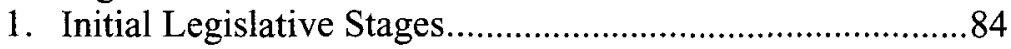

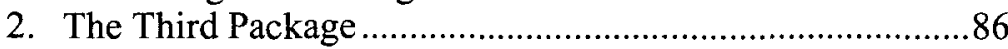

C. Implementing Measures the EU Way .....................................87

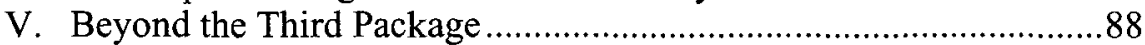

A. Escaping the Command-and-Control Box................................89

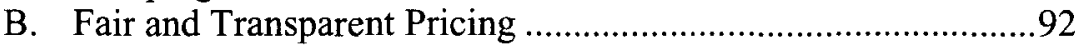

C. Viable Cross-Border Market ...................................................94

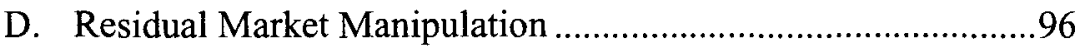

E. Access to Information..........................................................97

F. Reliability and Long-Term Planning ..........................................98

* Dudley W. Woodbridge Professor of Law, William and Mary School of Law. B.A., University of Maryland, 1966; J.D., George Washington University, 1969; LL.M., University of Chicago, 1975. I would like to thank the organizers of and participants in the Montpellier administrative law forum, especially Prof. Russell Weaver. Thanks also goes to Prof. Javier Guillen Carames, Universidad Rey Juan Carlos, Madrid and the participants in "Problemas Actuales del Derecho de la Competencia en el Sector Electrico" in which I first introduced some of these ideas. 
G. Industry- and Market-Participant-Driven Collaborative Governance Creates Motivations Toward Conservation and Alternative Fuels.

H. Collaborative Governance and "Third Countries" 101

\section{INTRODUCTION}

Both the European Union and the United States are engaged in the "restructuring" of their electricity industries. In a major conceptual break from the past, both societies see that specially designed markets can function in that industry. Yet, while market strategies are feasible in the generation and distribution/marketing segments, the bulk or wholesale transmission segment - the "big wires" that connect the generators with the consumers-challenges market solutions. The EU Commission has recently proposed a new round of restructuring legislation, known as the "third package." The EU reforms rely generally on command-and-control regulation to assure the public regarding performance by bulk transmission entities. The U.S. experience suggests that the European Union is trying to "do it the hard way." The United States has been moving to an organizational model known in U.S. administrative law as "collaborative governance." Collaborative governance concentrates on broad participation, inclusion of all the stakeholders, and transparency to assure the public regarding performance. This article examines the problems identified in the third package as they might be met - and to a large extent as they have been met in the U.S.- by the collaborative governance approach. Its goal is to generate a transatlantic dialogue on these issues.

The U.S. electricity industry has evolved a collaborative governance model and that model now dominates U.S. electricity restructuring. Significantly, the shift to this organizational model has been driven by the industry and market participants with government encouragement rather than command. Collaborative governance concentrates on joint problem solving and controlled discretion. ${ }^{1}$ It strives to be inclusive rather than adversarial by bringing into the governing entity itself all the stakeholders. It is based on public/private collaboration, founded on the interaction among governmental and private governmental-type entities. Because it is controlled by those directly affected, it naturally gravitates to

1. Jody Freeman, Collaborative Governance in the Administrative State, 45 UCLA L. Rev. 1, 22 (1997); Jody Freeman, Extending Public Law Norms Through Privatization, 116 HARV. L. Rev. 1285 (2003); see also Sallyanne Payton, "Professionalism as Third-Party Governance: The Function and Dysfunction of Medicare," in MAKING GovERNMENT

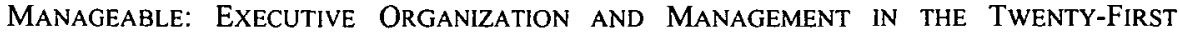
CENTURY 112-40 (Thomas H.Stanton \& Benjamin Ginsberg ed., Johns Hopkins Univ. Press 2004). Professor Payton has for years explored this concept in her course "Law of Cooperative Federalism." 
organizational structures dictated by technical and economic realities, rather than insisting on suboptimum political boundaries. Discussed below is the emerging U.S. collaborative governance model and how this model might address the problems recently identified by the EU authorities. ${ }^{2}$

\section{SHARED PROBLEM}

For generations, both Europe and the U.S. policymakers have assumed that the market cannot serve the public interest in the electricity industry. They assumed that the most efficient industry form is a monopoly or at least that the larger the firms, the better. The governmental task then seemed to be control of the market domination inherent in this industry structure. In the United States, the solution was regulated private monopolies while Europe tended toward state-managed monopolies. Today, on collective reflection, both societies now see that specially structured markets can be an improvement over either direct regulation or direct government control.

A pure market solution in all electricity regimes is challenged by three characteristics. First, the product is totally undifferentiated. Second, the product cannot be economically stored and hence it is the ultimate perishable commodity. Third, it cannot be directed from a source to a specific end user but must be made to flow toward that user. This last characteristic creates the greatest challenge to market solutions. Identifying an actual exchange of a particular product between the producer and the consumer is at best a fiction. A generator adds some artificially designated quantity of electricity into the flow and a consumer "pulls" those artificially designated units out of the flow. The generator may charge for adding the quantity and the consumer may be charged for taking that quantity out, but only in the most abstract and largely dysfunctional way may a consumer be said to purchase the electricity from a specific producer. ${ }^{3}$ Yet, while the producer does not actually sell the electricity

2. The most recent iteration of the EU electricity policy is called the Third Package. Two proposals in this Third Package are the focus of this discussion: "Proposal for a Directive of the European Parliament and of the Council amending Directive 2003/54/EC of the European Parliament and the Council of 26 June 2003 concerning common rules for the internal market in electricity et al." (hereinafter Internal Market Proposal); "Proposal for a Regulation of the European Parliament and the Council Amending Regulation (EC) No. $1228 / 2003$ on conditions for access to the network for cross-border exchange in electricity" (hereinafter Cross-Border Proposal). The Third Package was supported by a Commission study: "Green Paper: A European Strategy for Sustainable, Competitive and Secure Energy" (2006) (hereinafter Electricity Green Paper).

3. The market obstacles presented by these characteristics can be envisioned by considering a person in Spain buying a cup of water from someone in the United States. The person in the United States delivers the water by pouring it into the Atlantic Ocean; the purchaser dips a cup of water out of the Ocean. In theoretical compliance with the contract, 
produced to the consumer, it is increasingly recognized that a market solution can be pursued. The generators may be made to compete and the consumers may capture the benefits from this competitive market. In order to do so, however, the market solution must be adjusted to the special nature of electricity. These industry characteristics present a conundrum for every designer of a public-regarding electricity industry, American (both continents), European, Asian, and increasingly the remainder of the world. ${ }^{4}$

The first step is segregation of the three major segments of the industry and developing competition in production and distribution/marketing. The PJM website offers a helpful illustration of how an electric power system operates. ${ }^{5}$

\section{PROFILE OF THE ELECTRICITY SYSTEM ${ }^{6}$}

Both EU and U.S. restructuring then begins with "unbundling" these three segments-i.e., separating control (and/or ownership) of generation, bulk transmission, and distribution/marketing.

Bulk transmission presents the challenge. In a pure market approach, the generators must "buy" competitively priced transmission and that price must be included in the retail price. Unfortunately, bulk or wholesale transmission-the "big wires" that connect the generators with the consumers-do in fact meet the condition for a "natural monopoly." An ordinary market in transmission is inefficient, if not impossible. On the other hand, control of the big wires represents a dominant, "bottleneck" position which can cancel the market solutions in the generation and distribution/marketing segments. Thus, the challenge in creating an electricity market is structuring a market-friendly bulk transmission system

the seller delivered a cup into the system and the buyer took a cup out. Yet it is hard to even claim that the buyer bought the seller's water. The transportation of the seller's cup never really takes place and the cup withdrawn really comes from an unidentifiable source. This is electricity. One operating abstraction has been the "contract path fiction," in which everyone ignores reality. This fiction creates distortions in the market of electricity. Answers begin with thinking outside the bilateral contract thinking.

4. See generally Thomas von Danwitz, Regulation and Liberalization of the European Market-A German View, 27 ENERGY L.J. 423 (2006); Tun-jen Cheng \& Chung-min Tsai, "Powering Rent-Seeking in China's Electricity Industry," in RENT-SEEKING IN CHINA, (Tagwing Ngo \& Yong-ping Wu eds. 2008); Larry Pascal, South American Electricity-2006 Year in Review, 13 LAW \& BUS. REV. AM. 335 (2007).

5. Profile of an Electric Power System, http://www.pjm.com/about-pjm/how-weoperate.aspx.

6. Profile of the Electricity System, http:/www.pjm.com/about/overview.html.

7. A "natural monopoly" exists where the firm's average cost continues to fall within any feasible range of production and hence one producer can produce all requirements at the lowest cost. JaCk Hirshleifer \& David Hirshleifer, Price Theory and APPlications 241-42 (6th ed. 1998). In electricity, the advantage derives not just from "economies of scale" but also a vague concept called "subadditivity." PETER Fox-PENnER, Electric UTILITY RESTRUCTURING: A GUIDE TO THE COMPETITIVE ERA 8 (1997). 
in light of the three special characteristics of the electricity.

The challenge then is to enable a competitive market among generators and retail marketers-industries we now understand may efficiently operate under conditions of competition-when the producers can only be said to add to the flow from which the distributors/marketers draw when the flow is controlled by a bottleneck entity. For most of the 20th century, the solution was a vertically integrated utility that generated, transported, and marketed the electricity. The consumer simply contracted with the utility; the rest of the operation was coordinated within the utility. The utility coordinated the generation, transmission, and marketing of electricity. This vertically integrated industry presented serious economic and social problems. ${ }^{8}$ Since this monopolist could and did act as a monopolist, this structure presents the danger of a social "welfare loss" in which the system produces less electricity at a higher price than would a market. ${ }^{9}$ This welfare loss was addressed by some sort of government intervention, either regulation or direct government management (i.e., nationalization).

Both solutions created their own distortions, including inadequate control of the performance of the integrated entity. Regulation became more about politics and advocacy than efficiency. National ownership faced both direct political pressures and the inherent deficiencies of lack of economic incentives and bureaucratic decisionmaking. Both European and U.S. societies sought ways to break out of this box. The answer was sought in more nuanced market orientation and less direct government involvement. Yet the special nature of an electricity industry has not changed and the obstacles to a market approach are still present. In the end, the laws of physics still rule and the laws of man must still yield place to nature's laws. The United States and the European Union (and the world) share this problem and should dialogue on solutions. While this paper highlights an emerging U.S. solution, it does so to further a global dialogue.

8. On the other hand, it should not be forgotten in the enthusiasm for market coordination that the "theory of the firm" literature demonstrates the potential efficiencies of this model: "[Firms were created for] two interrelated reasons: (1) to take advantage of team production, and (2) to reduce contracting costs." Hirshleifer, supra note 7, at 160 . The second in particular should give some pause for the electricity unbundling projects.

9. Hirshleifer, supra note 7, at 237 ("In comparison with the competitive outcome, monopoly involves a transfer from consumer to suppliers. There is also an efficiency loss...."). 


\section{EVOLUTION OF U.S. ELECTRICITY POLICY}

\section{A. Major Shift in U.S. Regulatory Strategy}

A major shift in the theory of U.S. electricity regulation started not with Congress or administrative authorities such as the Federal Energy Regulatory Commission (FERC) or the Department of Energy (DOE), but with antitrust litigation. ${ }^{10}$ The story begins with the Supreme Court's opinion in Otter Tail. ${ }^{11}$ Since the end of the 19th century, the electricity industry was always considered a "natural monopoly" and hence ordinary application of the competition laws was deemed inappropriate. This theory spawned regulatory regimes in which rate and performance regulation aimed to create the performance of a competitive market while retaining the costeffectiveness of the monopoly. While some economists increasingly questioned this theory, a policy shift would not take place until the Supreme Court in Otter Tail found that competition was possible and that the electricity industry to the extent possible should incorporate market forces.

Congress made a few tentative attempts to encourage a market approach. ${ }^{12}$ However, it was FERC that initiated the first meaningful step toward restructuring the industry. The real beginning of efforts to inject market elements into the whole electricity industry was a FERC rule called Order $888 .{ }^{13}$ This "open access rule" provided an impressive foundation for this restructuring. ${ }^{14}$ Order 888 ordered functional unbundling, finding that ownership divestiture was not necessary. It sought to divide control of the three industry segments-generation, transmission, and distribution/marketing. A market in generation seemed plausible if the generators were separated from the integrated utilities. Likewise, a market

10. The two most significant and lasting pieces of early energy legislation relevant to this discussion are Part II of the Federal Power Act, 16 U.S.C.A. $\$ \S 824 a-825 r$, passed in 1933, and the Natural Gas Act, 15 U.S.C.A. $\S 717$ et seq., passed in 1938.

11. Otter Tail Power Co. v. United States, 410 U.S. 366 (1973). This case is seminal because it recognized the possibility of competition in the electricity industry and hence began the restructuring movement. Significant even today is the example of abusive behavior by the large, integrated utility. The utility attempted to drive out competition from small municipal utilities that were able to sell electricity well below the dominant utility. Such conduct continues to be a potential danger.

12. Major efforts include the Public Utility Regulatory Policy Act of 1978 (PURPA) (encouraging limited generator competition) and the Energy Policy Act of 1992 (expanding the types of generators that could sell deregulated wholesale power).

13. Order 888, Promoting Wholesale Competition Through Open Access NonDiscriminatory Transmission Services by Public Utilities; Recovery of Stranded Cost by Public Utilities and Transmitting Utilities, 61 Fed. Reg. 21,540 (May 10, 1996) (to be codified at 18 C.F.R. pts. 35,385 ) (hereinafter Order 888).

14. It was adopted through the basic U.S. "legislative rules"--rules made pursuant to delegated authority which have the "power of law"- set out in $\S 553$ of the Administrative Procedure Act (APA). The statement accompanying this rule is an impressive example of this process. 
in distribution would be created if customers were able to choose among retail marketers. Again, the key was separating the distribution segment from the integrated utility. Markets at the two ends, so to speak, proved possible, if not without difficulty. However, a traditional market in transmission-the operation of the big wires-eluded even theoretical designs. Transmission had to be an integrated whole and yet the countermarket opportunities remained after unbundling. To confront these opportunities, FERC looked to a structure that had been developed by members of the industry itself. It encouraged reorganization in which bulk transmission would be managed by not-for-profit organizations called independent systems operators (ISOs). ${ }^{15}$

Europeans must be immediately alerted to the fact that ISO organization as used in the United States is almost the exact opposite from the independent system operator option offered as an alternative by the EU Commission. The U.S. version of ISO is a not-for-profit system manager but the EU uses the term to designate an ordinary business entity:

This option, a derogation from the basic ownership unbundling approach, is know as the "Independent System Operator." This option enables vertically integrated companies to retain the ownership of their network assets, but requires that the transmission network itself is managed by an independent system operator-an undertaking or entity separate from the vertically integrated company-that performs all the functions of a network operator. In addition, to ensure that the operator remains and acts truly independently of the vertically integrated company, regulation and permanent regulatory monitoring must be put in place. ${ }^{18}$

Thus, the EU version of the ISO does not differ from the "preferred" version, except in the ISO alternative the ownership remains with the utility and in the preferred version the ownership is separated-but not by much. Neither alternative matches the U.S. ISO concept in which the focus is not on ownership but on management by an entity governed by all the stakeholders and hence truly independent.

This management organization of the big wires was in some sense privileged by FERC's open-access structure. Furthermore, embedded in the FERC open-access options was a move toward regional (multistate) design. Regional Transmission Organizations (RTOs), already existing in many regions, preside over an entity whose function was divided geographically according to the most efficient and effective physical and economic organization. In the original Power Act, Congress carved out,

15. For a history of U.S. electricity restructuring, see RICHARD F. HIRSH, POWER LOSS: THE ORIGINS OF DEREgULATION AND RESTRUCTURING IN THE AMERICAN ELECTRJC UTILITY SYSTEM (1999).

16. Internal Market Proposal, supra note 2, at 5-6. 
largely for political reasons, a role for state regulators. ${ }^{17}$ It became established doctrine that states were given jurisdiction to regulate "retail" and the federal regulators retained power over "wholesale." 18 Order 888 envisioned a structure in which federal regulation would impose optimum markets with necessarily softened state-defined industry components. In New York v. FERC, the Supreme Court strongly affirmed the FERC approach. ${ }^{19}$

\section{B. The ISO/RTO Solution}

FERC made a very wise choice: it encouraged the industry itself to offer open-access designs that eliminated anticompetitive control from a central entity. Almost a natural consequence of unbundling was industry shift to ISO/RTO models. ${ }^{20}$ This organizational model, which had emerged over sixty years, manages the big wires and usually makes a market in electricity, unencumbered by state or, in some cases, national boundaries. It also provides auxiliary services, control of which also presents the potential for anticompetitive conduct. In North America, ISOs and RTOs represent $67 \%$ of electricity customers in the United States and over half of those in Canada. ${ }^{21}$

This Article centers on the ISO/RTO model. The model's chart is available on the ISO/RTO Council's website. ${ }^{22}$ The discussion below generally equates interconnection among U.S. states with that among EU Member States. As can be seen from this chart, however, to be discussed further below, there is considerable cross-border cooperation between ISOs

17. See Rhode Island Pub. Util. Comm'n v. Attleboro Steam \& Elec. Co., 275 U.S. 83 (1927) (holding that the states could not regulate industries in interstate commerce and hence, for the states to have jurisdiction, the power had to be delegated by the federal government).

18. Fed. Power Comm'n v. Conway Corp., 426 U.S. 271, 276 (1976) ("The prohibition against discriminatory or preferential rates or services imposed by $\S 205$ (b) and the Commission's power to set just and reasonable rates under [FPA §] 206(a) are accordingly limited to sales 'subject to the jurisdiction of the Commission,' that is, to sales of electric energy at wholesale. The Commission has no power to prescribe the rate for retail sales of power companies.").

19. New York v. FERC, 535 U.S. 1 (2002). Indeed, Justice Thomas, in a separate opinion, found that FERC had jurisdiction over transmission transactions including those taking place within a state. See id. at 42 (Thomas, J., concurring in part and dissenting in part) ("Finally, to the extent that FERC has concluded that it lacks jurisdiction over transmission connected to bundled retail sales, it ignores the clear statutory mandate.").

20. 18 C.F.R. $\$ 35.34$ (2006) (setting out FERC's technical requirements).

21. ISO/RTO COUNCIL, HARNESSING THE POWER OF DEMAND: HOW ISOS AND RTOS Are INTEgrating Demand Response into Wholesale Electricity Markets (2007), http://www.isorto.org/atf/cf/\%7B5B4E85C6-7EAC-40A0-8DC3-003829518EBD\%7D/IRC _DR_Report_101607.pdf.

22. ISO/RTO 
in Canada and the United States. The organizational union often operates as if it were one entity. Thus, the organizational structure transcends political borders and may be seen as operating across international as well as interstate borders. The freer from political constraints in general, the more likely the boundaries will be determined by physical and market efficiencies. But, relevant to this paper, the greater the variety of private and governmental stakeholders brought into these entities, the greater the challenge to their governance organization.

\section{Collaborative Governance Model in Electricity}

Participatory governance is essential to the comfort level of firms that cede some control to an independent authority. For this reason, ISO/RTO governance enhances industry participation in joint action to facilitate efficient markets and reliability. Equally important, however, is that ISO/RTOs provide direct participation by nonindustry stakeholders, including consumers and various governments. The ISO/RTO model's inclusiveness and transparency gives it legitimacy. The collaborativegovernance strategy of the ISO/RTO system, then, is a key to its success.

Collaborative governance seeks to reorient the conceptualization of administrative process around techniques of joint problem solving and controlled discretion. ${ }^{23}$ It seeks an alternative to adversarial government and explores concepts and processes which might replace interest-group contests with cooperation and dialogue. ${ }^{24}$ It fosters the development of a coherent theoretic framework for those experimenting with alternatives based on positive problem solving rather than contestibility and coercion. It engenders information sharing, accountability, and broad participation and deliberation. ${ }^{25}$ It enables evolutionary decisionmaking in which solutions to immediate problems do not foreclose rethinking of both solutions and goals. It envisions synergistic government and broadens potential roles of public agencies, such as serving as facilitators and

23. Collaborative governance is characterized by five features: problem-solving orientation; participation by interested and affected persons at all stages of the decisionmaking process; solutions that are provisional and subject to revision; accountability; and flexible, engaged government institutions. Freeman, supra note 1, at 22.

24. Americans, not just their lawyers, have a great deal of difficulty with such behavioral norms. Much of the rest of the world finds it easier to engage in community dispute resolution. Our instinctive competitiveness is our strength and our weakness. Here, as perhaps elsewhere, this instinct can inhibit the attainment of the ultimate goal. Our inability to engage in cooperative decisionmaking may accrue to our comparative disadvantage in the increasingly interconnected world.

25. See Jim Rossi, Participation Run Amok: The Costs of Mass Participation for Deliberative Agency Decisionmaking, 92 N.W. U.L.REv. 173 (1997) (explaining that, while U.S. administrative law exults participation, the central consideration must be optimizing deliberation). 
information clearinghouses. Yet, while government may guide and monitor performance, it does not dictate operations. As Professor Freeman observed, "A collaborative perspective requires that we reconceive the relationship and responsibilities among public and private actors in the regulatory process." ${ }^{26}$ For these reasons, it seems to speak directly to the evolving electricity industry.

Through the ISO/RTO model, the collaborative-governance package has transformed governance in the electricity industry. Careful attention to the instrumental value of participation as well as its normative value is nowhere more important that in electricity governance. Indeed, collaborative problem solving changes the conceptualization of the interaction among the interests. Electricity governance is a complex prisoner's dilemma in which individual self-interest may in fact diminish the payoff for everyone, unlike most business relationships in which competition has social value. Mutual trust is obviously not enough and hence positive governance is necessary. The governance structure must be effective and fair-and appear to be effective and fair. The ISO/RTO model then serves the complex problem-solving challenges of the electricity industry. At the same time, it satisfies all the various interests in which they are involved in substance as well as form.

The oldest RTO, PJM, may well serve as an exemplar. ${ }^{27}$ This RTO originally managed grids in the neighboring U.S. states of Pennsylvania, New Jersey, and Maryland; hence its name. PJM was started by electric utilities in 1927 and became the first FERC-certified RTO in 1997. It has been extremely successful, growing to include 450 members in $15 \mathrm{Mid}$ Atlantic states. It manages over 56,000 miles of transmission lines and $164,905 \mathrm{MW}$ of generation. PJM covers 1,271 generating sources and serves over 51 million customers. Thus, it fosters vibrant competition between producers and provides choices for customers and marketers.

In the PJM governance system, the central authority is the Board of Managers. The Board is charged with operating a fair, nondiscriminatory electricity market. The Board may have no person who has a personal affiliation or ongoing professional relationship or financial stake in any PJM market participant. A Members Committee provides advice to the Board. That Committee has representatives from the key segments: generators, transmission owners, distributors, marketers, and consumers. A Nominating Committee fills vacancies on the Board. Various specialized committees, such as the Reliability Committee or the Finance Committee,

26. Freeman, supra note 1, at 97.

27. A great deal of information about the issues discussed here and otherwise is available on the PJM website, http://www.pjm.com. 
work to refine and improve rules, policies, and processes. Input also comes from user groups.

ISO/RTOs such as PJM engage in self-regulation of their various members. PJM's Market Monitoring Unit guards against the exercise of market power by any market member. The industry itself developed this concept to engender trust among market participants, including competitors. The Unit analyzes market data and takes action to make structural or rule changes. Self-regulation has been very successful in several U.S. industries, such as the securities industry. Members of the industry itself are much harder to fool than government regulators. On the other hand, they are sensitive to the needs of industry participants. When self-regulation works, it is both more effective and less burdensome to the industry. An independent transmission organization responsible for the industry's integrity offers the most effective monitor. For one thing, selfmonitoring creates legitimacy in that part of the industry that cannot be protected by market forces. In the end, the industry benefits from keeping its own house clean rather than dealing with intrusive governmental interference.

Another advantage of independent transmission management is its dispute-resolution machinery. Any environment with so many actors will create numerous disputes. For example, sometimes generators are unable to meet their delivery promise, customers may not want the delivery, or repairs may be negligent or slow. An effective transmission manager must efficiently settle such disputes. An ISO/RTO has the status, resources, and independence to do so. It is a better alternative to government regulatory mechanisms or judicial dispute-resolution mechanisms.

In sum, the private government-like services-including management, rulemaking, enforcement, and dispute settlement-solve many of the governmental tasks without many of the disadvantages of direct governmental involvement. Such entities serve well the sophisticated and complex tasks involved in governing the core segment of the electricity industry, bulk transmission. Fairness, competence, efficiency, and legitimacy radiate out to the entire industry and ultimately to the society it serves.

\section{EUROPEAN DEVELOPMENTS}

The EU has confronted electricity restructuring at three levels: treaty revision, statute-like measures, and pan-European and Member State administrative implementation. A brief summary of EU developments is necessary here. ${ }^{28}$

28. For a brief overview of EU law and government, see CHARLES H. KoCH, JR., 


\section{A. Treaty Recognition of Energy}

The basic or "constitutional" documents of the EU have been created by the various treaties signed by European nations admitted into the Union (Member States). These operative treaties have been consolidated into one unified document, ${ }^{29}$ which combines two treaties: the Treaty on the European Union (TEU or Maastricht Treaty) and the Treaty Establishing the European Community (TEC) ${ }^{30}$ From time to time, an Intergovernmental Conference is convened to develop amendments to the treaties. The most recent conference adopted the Treaty of Lisbon, or "constitution lite," which will impose more explicit energy responsibilities on the EU institutions.

In a sense, energy drove the progenitors of the European Union. The European Coal and Steel Community (ECSC) in 1952 first brought together the founding nations and created the prototype of pan-European government. In 1957, as they formed the European Economic Community (ECC), they also established a community more directly focused on energy: the European Atomic Energy Community (EURATOM). Still, it was not until the 1992 Maastrich Treaty that the Member States identified energy as a major EU concern. Energy has become one of the most pressing problems confronting the European Union (and the world).

The Treaty of Lisbon, ${ }^{31}$ signed by the heads of EU Member States on December 13,2007, raised the status of energy in general perhaps to the level of the original four freedoms. ${ }^{32}$ The Treaty of Lisbon will add a new Title XX. This title for now will add an Article 176A to the consolidated treaty. Article 176A expresses, among other things, a commitment to panEuropean electricity industry. In paragraph 1 it states that EU energy policy would be built around a "spirit of solidarity between Member States." In particular, subparagraph 1(d) provides that that policy shall "promote the interconnection of energy networks." According to paragraph 2 , these objectives are generally to be accomplished through the

PRIMER FOR U.S. LAWYERS ON EUROPEAN UNION GOVERNMENT AND LAW (2008), $\mathrm{http} / /$ www.abanet.org/adminlaw/eu/jan2008primerversionkoch.pdf.

29. Basic treaties: Go to http://eur-lex.europa.eu/en/treaties/index.htm, then select "European Union-Consolidated Versions of the Treaty on European Union and of the Treaty Establishing the European Community." (Both the "Treaty on European Union" (TEU) \& "Treaty Establishing the European Community" (TEC)).

30. When the Lisbon treaty comes into force the TEC will become the "Treaty on the Functioning of the European Union," http://europa.eu/lisbon_treaty/index_en.htm. A new consolidated version of the Treaty will be created.

31. http://europa.eu/lisbon_treaty/index_en.htm.

32. The core of EU substantive law has developed from the "four freedoms": the free movement of goods, workers, capital, and the freedom of establishment and service. The law for each has evolved somewhat differently through legislation and judicial interpretation. 
"ordinary legislative procedure," formerly "co-decision." 33 Under the ordinary legislative procedure, legislative measures are adopted by a "qualified majority" or weighted majority of the representatives of the Member States under amended Article 251; hence an individual Member State may not "veto" most energy legislation. ${ }^{34}$

\section{B. Legislative Development Toward a "Third Legislative Package"}

Although establishing clear responsibility and competence, the Treaty of Lisbon amendments provide only a framework. Thus, it is the legislative process which will restructure the European electricity industry. ${ }^{35}$ In 2007 ,

33. Currently, TEC Article 249 establishes three types of legislation: "regulation," "directive," and "decision." Regulations are binding without further Member State action. Directives require further action. Decisions are only binding on those to whom they are addressed. Article 251 establishes a complex procedure for enacting legislation in which the Commission, Council, and European Parliament participate. This process will be changed little when the Lisbon Treaty is ratified.

34. It is only for fiscal policy, under paragraph 3, that a unanimous vote of the Members States is required.

35. For those unfamiliar with EU governance, a few words about the EU institutions brought to bear on the electricity industry will be necessary. The EU has five key institutions: the European Council, the Council of the European Union (Council), European Parliament (Parliament), European Commission (Commission), and the European Court of Justice (ECJ).

The European Council, distinct from the Council of the European Union, is made up of the ministers of the Member States, the Heads of State or Government of the Member States and the President of the Commission, assisted by the ministers for Foreign Affairs and a Member of the Commission. TEU Article 4 provides, "The European Council shall provide the Union with the necessary impetus for its development and shall define the general political guidelines thereof." Thus, it is directly involved in developing the energy agenda.

The Council exercises the legislative authority with parliament. Each Member State (there are currently twenty-seven) is represented on the Council by a minister, depending on the subject matter under consideration, who is authorized to commit their government. In fact, the Council, although nominally a single entity, assembles in one of nine configurations, one of which is Transportation, Telecommunication \& Energy (TTE). Joint action is taken by a vote of the representatives of the Member States. On energy matters, the Council votes will be weighed in rough approximation of the state's population, known as a "qualified majority." All the work of this Council is prepared or coordinated by the Committee of Permanent Representatives (COREPER).

The Parliament has joint legislative power with the Council. The Members of the European Parliament (MEP) are the only directly elected EU officials. It has a committee for "Industry, Research and Energy."

The Commission is the hub of the EU, having significant equivalent powers along with most of the administrative responsibilities. The Commission is an active participant in the legislative process and provides the bureaucracy that implements EU policies. The College of Commissioners are nominated by the Member States and are often assigned according to their expertise and/or the Member States' special interest in a subject area. The Commission is divided into departments known as Directorates General, which are responsible for a specific policy area and are headed by a Director General. The Energy commissioner may have direct responsibility for electricity, but competition, environment, consumer protection, and internal market are also involved in the development of energy 
the Commission sent forward its "third legislative package," dealing with electricity and natural gas. ${ }^{36}$ As the name suggests, these reports and recommendations are the most recent iteration of the long electricity restructuring process. They provide evidence that an internal market in electricity is still very much a work in progress.

\section{Initial Legislative Stages}

The process began before the first legislation, the "First Electricity Directive." ${ }^{, 7}$ Development is said to have begun with a Commission paper, "The Internal Energy Market" in 1988. The paper described a competitive market in all the energy markets, including electricity. It helped begin an "internal" pan-European market in energy. Parliament and the Council adopted various energy directives. Two of these dealt with electricity. The June 29, 1990 Directive 90/377/EEC sought to make the electricity market more transparent, and the October 29, 1990 Directive 90/547/EEC focused on the grid. $^{38}$

The so-called First Electricity Directive, Directive 96/92/EC of December 19, 1996, was the first significant step toward an internal electricity market. ${ }^{39}$ This Directive attempted to deal with the various complexities of restructuring the European electricity industry. The directive left a good deal of the liberalization to the Member States. As in the United States, this directive, for both legal and practical reasons, opted for "functional unbundling." required to separate their network operations from their other activities. The directive, as in the United States, recognized the limitations on the natural monopoly model. The Member States could choose to organize the

policy.

EU judicial authority is vested in the European Court of Justice (ECJ), assisted by the Court of First Instances. The ECJ has yet to take a substantial role in the development of energy policy. However, it has been a very active court and it can be expected to be increasingly inyolved as the other EU and Member State institutions focus attention of such matters.

36. ELECTRICITY GREEN PAPER, supra note 2.

37. For a more complete description of the evolution of EU energy policy see Danwitz, supra note 4, 433-40.

38. Americans should note that transparency connotes for Europeans a much broader set of values than for Americans. For Americans, transparency is virtually synonymous with openness. For Europeans, transparency includes not only openness, but also public sensitivity, participation, and good administration in general.

39. Directive 96/92/EC of the European Parliament and the Council of 19 December 1996 concerning common rules for the internal market OJ L027 (30/01/1997) (hereinafter 96 Directive).

40. In addition to the impossible political obstacles as in the U.S., divestiture may violate European human rights jurisprudence. See Danwitz, supra note 4, at 436-37. Some Member State courts may find that ownership unbundling violates property rights guaranteed by the national constitution. 
operating system either by negotiated supply contract (a regulated system in which access was based on published tariffs), or by a "single buyer" procedure in which the Member State designated an entity to be responsible for transmission management with a territory. The Member States could continue the "public service" principle, in which the company received protection from competition in exchange for an obligation to satisfy certain public service standards. However, this concept is in direct tension with a free internal market in electricity because it burdens the internal market with public-interest responsibilities. ${ }^{41}$

The Second Electricity Directive, Directive 2003/54/EC, repealed the First Directive. ${ }^{42}$ This Second Directive was based on the concept of electricity as a service and hence accepted limitations on competition. Still, it was intended to end distortions of competition caused by differences in Member State regulation. Most significant is the choice between "negotiated" access under the First Directive and regulated network access. ${ }^{43}$ Under the latter approach, the European regime accommodated a wide variety of different regulatory models. Danwitz offers three criticisms:

First, [the directive permits a] wide variety of obligations which member states can impose upon companies under their authority to regulate in the general economic interest.

[T]he Second Directive does not give member states any guidelines for how to ensure that companies active in the energy markets will be kept financially capable of providing services of general interest. Finally, member states can decide not to apply fundamental provisions of the Directive. $^{44}$

The directive also promotes renewables to address the climate-protection concern.

Both the first and second package established the Transmission System Operator (TSO) as the core of the bulk power transmission. The 1996 Directive found that,

[w] hereas each transmission system must be subject to central management and control in order to ensure the security, reliability and efficiency of the system in the interests of producers and their customers; whereas a transmission system operator should therefore be designated and entrusted

41. See generally Jim Rossi, The Common Law "Duty to Serve" and Protection of Consumers in an Age of Competitive Retail Public Utility Restructuring, 51 VAND. L. REv. 1233 (1998).

42. Directive 2003/54/EC of the European Parliament and of the Council of 26 June 2003 concerning common rules for the internal market in electricity and repealing Directive 96/92/92 (hereinafter Second Directive).

43. Germany is an example of the failures of negotiated approach. See Danwitz, supra note 4 , at $445-49$

44. Id. at 443 . 
with the operation, maintenance, and, if necessary, development of the system; whereas the transmission system operator must behave in an objective, transparent and non-discriminatory manner. ${ }^{45}$

It provides that

Member States shall designate or shall require undertakings which own transmission systems to designate ..., a system operator to be responsible for operating, ensuring the maintenance of, and, if necessary, developing the transmission system in a given area and its interconnectors with other systems, in order to guarantee security of supply. ${ }^{46}$

The EU has been committed to this path ever since.

The 1996 directive also required the creation of retail transmission entities called distribution system operators (DSOs). ${ }^{47}$ These entities form the delivery leg of the complete EU transmission system design, marketing/distribution. Obviously, DSO operations are part of a complete view of the European electricity system but their operation and organization are beyond the scope of this paper.

\section{The Third Package}

In 2007, the Commission submitted its third legislative package, proposing amendments to the 2003 legislation. The process toward the third package can be said to begin when the Commission published a March 8, 2005 "Green Paper" on developing a common, coherent European energy policy in response to a direction from the European Council. $^{48}$ (The Commission engages its own and outside experts to study an issue and often develops a Green Paper-a document intended to begin discussion-particularly within the EU institutions.) $)^{49}$

The legislative proposals attempt to correct defects in the regime brought about by the existing legislation. Unfortunately, choices made in the prior legislation make solutions more difficult. The choice of command-andcontrol regulation naturally results in even more intrusive and marketdistorting government intervention, as it did in the United States. The collaborative governance model offers another way. It offers an alternative that can and should be instituted by the European industry as it has been in the United States. Again, as in the United States, regulators should encourage their formation and then monitor their performance without injecting themselves directly into operations.

45. 96 Directive, supra note 39 , at 0025

46. Id. at Article 7(1).

47. Id. at Article 10(2).

48. Electricity Green Paper, supra note 2, at 105.

49. A "White Paper" contains a proposal for specific action. White papers may but do not necessarily follow a Green Paper. 


\section{Implementing Measures the EU Way}

The European industry is politically and, in general, technically fragmented into twenty-seven national industries. ${ }^{50}$ The legislative packages envision implementing measures at the pan-European and Member State levels. ${ }^{51}$ Unlike in the United States, the EU delegates most pan-European implementing authority to the Member States. ${ }^{52}$ This "constitutional" choice fundamentally distinguishes the EU "federalism" from U.S. federalism. ${ }^{53}$ The European system relies on the Member State legislatures and executive officials to implement EU law and hence results in a quite different configuration of the European administrative system. ${ }^{54}$ This basic distinction must be factored into the multistate aspects of the model advocated here but not the not-for-profit aspects.

Despite the utilization of Member State administrations, EU law is

50. For a discussion of each national segment, see Commission Staff Working Document Accompanying Document to the Communication for the Commission to the Council and the European Parliament: Prospects for the Internal Gas and Electricity Market, SEC (2006) 1707 (10.1.2007). See, e.g., id. at 62 ("The opening of the [electricity] market is still primarily theoretical in France.").

51. Agency categories recognize a coordination between national governmental institutions and European institutions. Mario Chiti, The Emergence of a Community Administration: the Case of European Agencies, 37 COMMON MARKET L. REV. 309 (2000). National agencies (which European scholars tend to lump together as "national regulatory agencies" or "NRAs") perform much of the European administrative functions. A growing number of EU agencies (European agencies or EAs) have taken on some of the administrative responsibility but even so they tend to coordinate with NRAs.

52. As in the United States, delegation is the fundamental issue. Theoretically, delegation of basic policymaking authority is prohibited. Meroni v. High Authority, [1958] ECR 11 (1957-1958)] \& [1958] ECR 53 (1958). See Jens-Peter Schneider, A Common Framework for Decentralized EU Agencies and the Meroni Doctrine, 61 ADMIN. L. REv. (SPECIAL EDITION) 29 (2009). In the United States, practicality has forced acceptance of the exercise of broad delegations. E.g., Mistretta v. United States, 488 U.S. 371, 372 (1989) ("Applying the 'intelligible principle' test to congressional delegations, our jurisprudence has been driven by a practical understanding that in our increasingly complex society, replete with ever changing and more technical problems, Congress simply cannot do its job absent an ability to delegate power under broad general directives."). EU law has been going through a similar evolution. Charles $\mathrm{H}$. Koch, Jr., The Devolution of Implementing Policymaking in Network Governments, 57 EMORY L.J. 167 (2007). To keep the theory alive but capture the reality, the Treaty of Lisbon will distinguish legislative actions from "nonlegislative acts" or delegated implementing policymaking. See new Article 249B ("A legislative act may delegate to the Commission the power to adopt non-legislative acts of general application to supplement or amend certain non-essential elements of the legislative act.").

53. Europeans should note that the U.S. Supreme Court has absolutely prohibited the "commandeering" of state and local legislative and executive branches. New York $v$. United States, 505 U.S. 144 (1992), invalidated federal efforts to direct state legislatures (even though the states asked for it), and Printz v. United States, 521 U.S. 898 (1997), invalidated federal efforts to command state and local executive officials.

54. See generally Paul Craig, Shared Administration, Disbursement of Community Funds and the Regulatory State, in LEgal Challenges in EU AdMinistrative LaW (Herwig C.H. Hofmann, ed.) (forthcoming June 2009). 
supreme when exercised. ${ }^{55}$ To date, however, the Council and European Parliament have not chosen to co-opt the Member State electricity authorities. Indeed, EU legislative efforts have forced regulatory bodies onto the Member States. ${ }^{56}$ Thus, the European Union is actually imposing the regulatory fragmentation that the United States is fighting to soften.

Existing and proposed legislative strategies do little more than authorize cooperation among the Member State regulatory bodies. The Commission has proposed no more than an Agency for the Cooperation of Energy Regulators. The Internal Market Proposal observes that,

[i]n practice, only a body emanating from the national regulators can catalyse all the necessary resources of national regulators that is [sic] fundamental to achieving success on these issues. The Commission is not in that position.

The Commission has concluded that the tasks required could be best

fulfilled by a separate entity, independent and outside the Commission. Both the European Council.$_{5 j}$ as well as recent European Parliament resolutions, endorse this conclusion. ${ }^{57}$

Hence, a FERC-like agency does not seem in the immediate future of the pan-European electricity industry. However, the European Union may ultimately move toward a more intrusive European-wide energy regulator. ${ }^{58}$ At present, eliminating geographic fragmentation must be the work of the industry itself, as in the United States not so long ago. The ISO/RTO model offers the device for doing so.

\section{BEYOND THE THIRD PACKAGE}

Those who have been involved with the U.S. electricity industry since before restructuring would say that the European Union is trying to do it the hard way. We say so confidently because the United States was stuck in the same box for generations. The EU vision is at base federalized command-and-control regulation. This vision is the one the United States is trying to escape. The way out for the United States has been a shift to employing truly independent transmission-management bodies, which are governed in such as way as to force sensitivity to the interests of all the

55. Although there is no EU supremacy clause, the European Court of Justice early on in Costa v. Ente Nazionale Per L'Engergia Elettrica (ENEL) firmly established that principle and has not been seriously challenged [1964] ECR 1141.

56. Directive 2003/54/EC of the European Parliament and of the Council of 26 June 2003 concerning common rules for the internal market in electricity and repealing Directive 96/92/EC, Article 23; Regulation (EC) No. 1228/2003 of the European Parliament and of the Council of 26 June 2003 on conditions for access to the network for cross-border exchanges in electricity. See Note of DG Energy \& Transport on Directives 2003/54/EC and 2003/55/EC on the Internal Market in Electricity and Natural Gas, "The Role of the Regulatory Authorities." (14/1/2004).

57. Internal Market Proposal, supra note 2, at 10.

58. Electricity Green Paper, supra note 2, at 6. 
stakeholders. The various levels of regulators then become the monitors and ultimate guarantors of the public regarding performance. This approach would better answer the goals identified in the Commission's third-package proposals.

\section{A. Escaping the Command-and-Control Box}

The United States has eased out of the command-and-control box by encouraging the industry to form itself around independent, not-for-profit managers of the bulk transmission segment, the ISO/RTO model. The U.S. industry itself in many regions was already moving to this basic organization. Increasingly the industry depended on multistate, not-forprofit systems operators to provide market mechanisms while maintaining the optimum transmission performance. This structure was attractive to industry because it enabled competitors and stakeholders to work in concert in their mutual interest.

In 1996, the federal government approach shift from adversarial industry/government scheme to command and control began with the foundational open-access regulation, Order $888 . .^{59}$ That first step recognized the public-interest advantages of collaborative governance in the move to "unbundling." Unlike the EU Commission, FERC abandoned reform strategies based on tightening command-and-control regulation. It charged the industry with the task of working out a viable restructuring plan which captured the efficiencies from coordination but structurally mitigated opportunities for collusion and discrimination. In terms of organization, FERC suggested only that it would look favorably on the ISO/RTO solution. In Order 2000, it established a template for RTOs but it still left to the industry the choice as to how structurally to accomplish the unbundling and open-access goals. ${ }^{60}$ The ISO/RTO solution increasingly recommended itself to the industry as well as the regulators.

Several approaches were tried, including a separate for-profit transmission operator, like the EU version of the independent systems operator. Many practical difficulties doomed this alternative. From a regulatory perspective, both FERC and the public doubted that these bottleneck, for-profit transmission operators would avoid conflicts of

59. Promoting Wholesale Competition Through Open Access Non-Discriminatory Transmission Services by Public Utilities; Recovery of Stranded Costs by Public Utilities and Transmitting Utilities, 61 Fed. Reg. 21,540 (May 10, 1996) (hereinafter Order 888).

60. The main framework for the development of transmission organizations and hence particularly relevant to this paper was provided by Order 2000, Regional Transmission Organizations, 65 FED. REG. 810 (Jan. 6, 2000) (hereinafter Order 2000). In that order, FERC established twelve characteristics and functions that an entity must satisfy in order to become an RTO. 
interests. Simply put, it seemed inevitable that the traditional business organization and the profit motive would ultimately drive these firms toward self-interested conduct.

The EU Commission increasingly commits to a regulatory, commandand-control strategy. The proposals in the third package call for stronger and more intrusive Member State National Regulatory Agencies (NRAs). The "federal" aspect of the industry was confronted through cooperation among these agencies. ${ }^{61}$ It continues the trend to an ever larger role for a pan-European agency but still not a pan-European electricity system. ${ }^{62}$ As was true in the United States, by relying on an adversarial governmental scheme, the EU motivates the industry to act adversarially. The regulatory fragmentation is perpetuated because a pan-European agency seems to face significant, if not impossible, political obstacles. ${ }^{63}$ The message from the United States is that this strategy is not in the rational best interest of the industry and the consuming public, although it might serve that of the bureaucrats.

Rather than depending on a pan-European regulator or further empowering the Member State regulatory bodies, the EU authorities might consider encouraging the U.S. ISO/RTO model. ${ }^{64}$ It is significant that in the United States these entities were developed by the industry itself. After generations of command-and-control schemes, FERC undertook in essence a partnership with these private governmental bodies. This shift in emphasis mitigates to a large extent a number of adversarial relationships inherent in the command-and-control regime: that between government and the industry; that between the industry and its customers; and that between industry members of various size and functions. In contrast, the path taken by the European Union pits the most dominant members of the industry against consumers of all varieties-competitors as well as governments. Customers in the EU scheme are left outside and hence can be expected to act as adversaries. After the unbundling, the generation and retail/distribution segments also must assume an adversarial relationship with the transmission segment. The collaborative governance organization created by the ISO/RTO model tempers these adversarial tendencies.

EU legislation does not seem to preclude not-for-profit TSOs but simply ignores that option. ${ }^{65}$ As noted above, the EU institutions, on the

61. Cross-Border Proposal, supra note 3 , at 8 .

62. See id. (listing regulatory powers).

63. Some evidence for this observation is the reaction to the proposal by telecom commissioner Viviane Reding for a pan-European agency for that industry. Sarah Laitner, Blow to Plan for Telecoms "Super" Regulator, FinANCIAL TIMES, Apr. 2, 2008.

64. Internal Market Proposal, supra note 3, at 8.

65. See Internal Market Proposal, supra note 3, at 5 N6 (discussing only the "two options"). 
recommendation of the Commission, have consistently centered European restructuring on Member State-oriented transmission-system operators (TSOs) as a for-profit business. U.S. open-access regulation leaves open the option of for-profit transmission organizations (broadly known as "transcos"), but those do not seem to survive. Perhaps destructive pressure comes from the fact that the other stakeholders and regulators distrust these business-motivated bottleneck entities. Indeed, it seems that even the participating competitors reach a level of dysfunctional distrust that ultimately ends each such endeavor. The U.S. experience may suggest that closed, for-profit bulktransmission entities present negative incentives that are hard to monitor through direct government regulation. Thus, this option is in direct conflict with a system that is trying to downsize its command-and-control approach.

The third package continues to center on the TSOs and that structure could be the beginning of a viable solution. Unfortunately, the European Union apparently assumes and accepts, as for years did the United States, that these entities would be organized and governed as any other business. ${ }^{66}$ The Commission proposal requires only that the TSO "consult" with stakeholders. ${ }^{67}$ On the other hand, in classic collaborative governance fashion, the ISO/RTO model brings all the stakeholders into the actual decisionmaking process, as can be seen in the discussion of PJM above. It is little wonder that this model has expanded so rapidly, serving $67 \%$ of the U.S. consumers and half of those in Canada. With those affected by the management of the big wires directly involved in their management, there is much more trust, and enhanced efficiencies result from the softening of adversarial relationships and the diminished need for direct command-andcontrol regulation. Again, the EU legislation may not preclude stakeholder-governed bulk transmission entities, but it also does not facilitate them. It should. More realistically, since government bodies hanker after the power inherent in direct regulation, the industry itself should develop and lobby for this option.

Replacing direct government regulation with the collaborative ISO/RTO model also tends to foster reliance on objective, expert decisionmaking. A decision must have sound technical support because all the stakeholders have to buy into the decision. Advocacy and power become less important. Decisions are more likely motivated by what is best for the system, and hence society, rather than what is best for an individual business entity.

66. Internal Market Proposal, supra note 3, at 5-6.

67. See Cross-Border Proposal, supra note 3, at 15 ("[S]takeholders will be consulted on any draft market and technical code prepared by the transmission system operators and they will be able to comment on the annual work programme of the transmission system operators." (emphases added)). 
Hence a look at the organization of the U.S. ISO/RTOs will discover a myriad of broadly representative study groups and expert task forces.

\section{B. Fair and Transparent Pricing}

As stated above, electricity has been considered a "natural monopoly." As such, the efficient organization would be one dominated by a single firm with "market" pricing artificially imposed by government. Thus, in the United States, the federal agency was required to assure that rates were "just and reasonable" at the wholesale level and the state regulators did the same at the state level. ${ }^{68}$ The present EU approach does not so empower a "federal" agency but delegates responsibility to the Member States. Member States engage in rate regulation. ${ }^{69}$

Regulating rates-setting nonmarket prices-has always been complex. ${ }^{70}$ By the end of the 20th century, energy policymakers in the United States, both legislative and administrative, had determined that the social costs of rate-making exceeded its social benefits. Since then, policymakers have attempted to move toward market-driven pricing. The ISO/RTO model has been instrumental in implementing market pricing in the complex electricity market. FERC has encouraged the voluntary participation in ISO/RTO by allowing those firms to rely on the tariff filing of the ISO/RTO. ${ }^{71}$ In Order 888, FERC offered a "pro-forma" open-access tariff whereby transmission providers could comply with their new marketrelated obligations. The ISO/RTO form is encouraged in order to make it easier to administer and enforce these obligations. Even though the states continued to regulate retail prices, the ISO/RTO system promotes uniform, market-driven prices for bulk-transmission access.

Europe has an advantage in that, at this point, it will not need to wean itself away from a pan-European price regulator. Fortunately, its reform efforts do not seem to envision such rate regulation. The third package, and throughout the evolution of EU restructuring, focuses almost no attention on pricing. Nonetheless, as bulk transmission escapes Member State borders, pricing must also become a pan-European interest. The

68. See Fed. Power Comm'n v. Conway Corp., 426 U.S. 271, 276 (1976) (explaining that the Federal Power Act provides that the federal agency regulates wholesale and the states regulate retail).

69. Commission Staff Working Document accompanying document to the Communication from the Commission to the Council and the European Parliament: Prospects for the Internal Gas and Electricity Market COM (2006) 841 (covering all the Member States but Bulgaria and Romania).

70. See, e.g., ESSAYS ON PUBLIC UTILITY PRICING AND REgUlation (Harry M. Trebing ed., 1971).

71. On February 16, 2007, the Commission issued Order 890 adopting certain refores of the pro forma tariff. 
fragmented regulation, in fact required by EU legislation, means that panEuropean transmission must contend with various pricing schemes. Thus, the Commission's approach to pan-European regulation seems the worst of both worlds. Wholesale power will not be subject to European pricing regulation, in contrast to the United States, but will be subject to Member State rate regulation. For one thing, this fragmented price regulation means that it will be much harder to dismantle bulk-transmission pricing schemes defined by political rather than economic borders.

The elimination of retail price regulation is a more complex question not apparently solved through the ISO/RTO model. Simply put, small business and individual consumers do not seem to take advantage of market opportunities. Even though the ISO/RTO model includes consumer representatives, it has not been successful in this regard. It probably is not sufficiently sensitive to the weakness of small industry and residential representation. ${ }^{72}$ Even if such a governance breakthrough could be achieved, however, these consumers will likely continue to behave in the market as they did under the integrated utility regime. Indeed, what economists call "search costs" might make it irrational for them to behave otherwise. Their welfare concerns are aggravated by the wholesale-retail price squeeze. ${ }^{73}$ Pricing throughout the network dictates retail pricing. If care is not taken with network pricing, small business and residential consumers are merely stuck between noncompetitive costs and competitive or regulated prices. Retail marketers who potentially could make markets for such consumers are powerless against this market- structure dilemma. In short, U.S. states continue to engage in retail price setting, and it is hard to argue against their doing so even though such price regulation artificially fragments the market. A multistate solution would be preferable but does not seem imminent.

Realization of a true pan-European internal market faces the same "street-level" obstacles. The EU Commission might have hoped that the DSOs would facilitate a viable retail market. Yet as the internalmarket proposals found, "Neither in the electricity and the gas market is it yet possible to speak of a European retail market (household and small enterprise), as customers, assuming they have a choice, are still obliged to

72. For further discussion of this problem in the United States, see Charles H. Koch, Jr., Collaborative Governance in the Restructured Electricity Industry, 40 WAKE FOREST L. REV. 589, 602-604 (2005) ("Fair RTO governance ... must assure that the small consumers [small business and residential consumers] are not submerged within a universal 'consumer' interest as defined by large industrial and commercial consumers.").

73. See Greg Goelzhauser, Price Squeeze in a Deregulated Electricity Power Industry, 32 FLA. ST. U. L. REV. 225, 241 (2004) ("Although electric power firms' rates are regulated to some extent, a squeeze may arise due to actions of the differing bodies that set or approve the rates: FERC at wholesale and state regulatory commissions at retail."). 
choose a supplier established in the same country."74 The third package does attempt to confront the problems of the retail market, but the Commission presentation can only be termed pessimistic.

Both systems then may have no alternative but to accept retail-price regulation. True to the theme of this piece, it may be that the collaborative governance of the ISO/RTO can be designed to offer a non-governmental remedy. It cannot at this point be said that it has succeeded in doing so. While it might seem that European and American consumers are different, they may be similar enough to make a transatlantic dialogue on this conundrum valuable to both.

\section{Viable Cross-Border Market}

One aspect to true pan-European competitive pricing is allowing the industry to reach its natural physical and market boundaries. Not only must former national monopolies not be allowed to discriminate among compatriots, but attainment of an internal market requires nondiscrimination within a pan-European industry. Europe is already significantly interconnected and those interconnections are increasing. This condition parallels that in the United States during the initial stages of the open-access project.

In both the United States and the European Union, as energy needs overcome politics, the systems have become increasingly and more transparently interconnected. The Union for the Co-ordination of Transmission of Electricity (UCTE) has created a map showing the physical energy flows between European countries, which is available on the UCTE website. ${ }^{75}$ A U.S. Department of Energy study, for example, observed "three major interconnected power systems: the Eastern and Western Interconnection, and the Electricity Reliability Council of Texas (ERCOT) False Today, over 150,000 miles of high-voltage transmission lines link generators to load centers through interconnected transmission systems that span utility services, territories, states, regions, and the borders of Mexico and Canada." Similarly, as described below, Europe is increasingly interconnected, and the grid naturally divides into multistate regions not constrained by political borders. Practical impetus simply rolls over these borders in the absence of overwhelming political will.

Still, the Green Paper observed: "Many markets remain largely national,

74. Internal Market Proposal, supra note 3, at 18.

75. Final Report, Implementation of TEN-E project (2004-2006): Evaluation and Analysis, http://www.ucte.org/_library/statsexchange/e_exchanges_2005.pdf

76. U.S. Department of Energy, National Transmission Grid Study, 2-3 (2002), $\mathrm{http} / / / \mathrm{www}$.ferc.gov/industries/electric/indus-act/transmission-grid.pdf. 
and dominated by a few companies. Many differences remain between Member States' approaches to market opening, preventing the development of a truly competitive European market false." 77 It asserted that consumers "need a single European grid." The Internal Market Proposal suggests a "supra-national" transmission operator. ${ }^{78}$ However, it seems wedded to the idea of cooperation among national TSOs rather than actual cross-border entities. Among other things, its suggestion comes close but ultimately misses the point by confining its thinking to interconnected systems of industry participants segmented by national borders. It does not see that the inability to think outside this particular box results in an unsatisfactory level of interconnection. ${ }^{79}$ Thus, while its first "concrete proposal" is the development of a European Grid, it does not see the overarching importance of the governance of that grid in accomplishing that goal. ${ }^{80}$

These state-defined systems---even if physically interconnected-cannot optimally serve the public interest. All EU institutions nominally support transnational interconnects. ${ }^{81}$ The TEN-E project study shows significant advances in cross-border interconnections. ${ }^{82}$ These interconnections increasingly are aimed at power-market goals between national systems, rather than only supplying security. ${ }^{83}$ The EU recognizes the need for one or more grids without political borders. The Commission observed the lack of incentive to pursue all feasible and advantageous interconnections; ${ }^{84}$ it hopes that these business entities will cooperate. ${ }^{85}$ As Adam Smith observed some years ago, business people coming together is never good for the rest of us. ISO/RTO enables grid cooperation with much less opportunity to jointly act against the public or competitors. Indeed, it evolved from business people, both industry members and their customers, seeking an cooperative organization they could trust.

Fragmented regulation is also a major obstacle to an efficiently organized internal market. The Internal Market Proposal laments the difficult technical problems caused by the various Member State regulations. ${ }^{86}$ In the United States, a national regulator was already in

77. Electricity Green Paper, supra note 3, at 5.

78. Internal Market Proposal, supra note 3, at 7.

79. Id. at 6

80. Id. at 18 .

81. Cross-Border Proposal, supra note 3 , at 3.

82. MVV Consulting, "Final Report: Implementation of TEN-E Project (2004-2006) Evaluation and Analysis" (27/7/2006).

83. Cross-Border Proposal, supra note 3, at 19.

84. Id. at 4.

85. Id. at 13

86. Internal Market Proposal, supra note 3, at 10 ("At present the technical rules that electricity companies must operate under, 'grid-codes,' differ enormously between Member States and often even within a single Member State."). 
place and it needed only to step back from direct involvement. Thus, FERC could both mandate multistate solutions and withdraw commandand-control regulation in order to foster an industry unconstrained by political borders. The industry-driven cross-border uniformity was a natural result, and the not-for-profit entity, acting transparently and inclusively, prevented collusion and discrimination. In the Green Paper, the Commission promised to examine "whether existing forms of collaboration between national regulators and national operators are adequate, or whether a closer level of collaboration is needed-with for example a European energy regulator to look at cross-border issues." ${ }^{.87}$ The Commission has proposed for an Agency for the Cooperation of Energy Regulators. The lesson from the U.S. experience is that regulatory cooperation will not get the job done.

\section{Residual Market Manipulation}

The Commission identifies a persistent problem with functional unbundling: ${ }^{88}$ "Firstly, the transmission system operator may treat its affiliated companies better than competing third parties." As the Commission further recognized, "This inherent conflict of interest is almost impossible to control by regulatory means as the independence of the transmission system operator within an integrated company is impossible to monitor without an excessively burdensome and intrusive regulation." To solve this problem the Commission's "preferred option... remains ownership unbundling." 89 As in the United States, ownership unbundling meets strong resistance. Indeed, in some Member States it may be a violation of fundamental rights. ${ }^{90}$

Evidence from the U.S. experience is that even ownership unbundling does not prevent discrimination against "outsiders" or collusion among "affiliates." The ISO/RTO model includes "market monitoring" operations. This self-regulatory regime is preferable to direct-conduct regulation and the threat of direct regulation strengthens the hand of private-market

87. Electricity Green Paper, supra note 3, at 6.

88. Internal Market Proposal, supra note 3, at 4.

89. Id. at 5; see also Cross-Border Proposal, supra note 3, at 3-5 (separate shares for each entity).

90. Danwitz, supra note 6, at 436-437:

As to the forced transfer of ownership to new legal entities: "The expropriation of the network operators ... would require considerable restriction on fundamental property rights of private companies which are protected both by European Law and by the constitutional law of the member states ...."

As to transfer of control to independent entities, the German Constitutional Court has held that option to be de facto expropriations because "the legal position would be essentially worthless due to the complete loss of influence on the network." 
monitoring. Indeed, this possibility may be one of the reasons industry members voluntarily committed themselves to this regime. More importantly, the industry is likely to police itself more efficiently and effectively provided it has the incentives to do so.

Still, it is clear that some government oversight is desirable and nonetheless inevitable. ISO/RTO market-monitoring operations offer a self-regulatory remedy for discrimination and collusion, but this solution has not answered all skeptics. Moreover, a substantial segment of the U.S. market is not encompassed in an ISO/RTO model. Congress recognized that market manipulation is still a factor in the U.S. electricity industry and therefore enacted the Energy Policy Act of 2005 (EPAct). ${ }^{91}$ The EPAct, among other things, gave FERC increased authority to issue rules to prevent market manipulation in wholesale electricity transmission. ${ }^{92}$ The Act empowers FERC to impose "civil penalties" for violation of these rules.

The U.S. experience then suggests first that, to the extent possible, the system should permit and encourage self-regulation. Thus, a broadly representative private organization should develop the conduct rules and enforce them. On the other hand, government regulators should not be far removed. They must monitor these self-regulatory efforts. These monitoring activities might take place at all governmental levels-federal, state, and local. Cooperation in monitoring, as opposed to direct regulation, adds effectiveness as well as uniformity. Monitoring is then the most efficient and effective regulatory role on both sides of the ocean. Both systems should gravitate in that direction. The United States may be coming at a new governmental role from a different direction than Europe, but it is hard to say it is ahead. It may simply have done more to dismantle and reconceive its direct regulation.

\section{E. Access to Information}

Information is the key to a viable electricity market and to preventing market manipulation. Thus, FERC, in Order 889 (accompanying the Open Access Order, Order 888), added rules establishing and governing an Open Access Same-Time Information System (OASIS). ${ }^{93}$ Its introduction summarizes the rules:

[E]ach public utility (or its agent) that owns, controls, or operates facilities

91. Energy Policy Act of 2005, Pub. L. No. 109-58, 119 Stat. 594. See generally Heather Curlee, Examining EPAct 2005: A Prospective Look at the Changing Regulatory Approach of the FERC, 63 WASH. \& LEE L. REV. 1649 (2006).

92. 16 U.S.C. $\$ 824 \mathrm{v}(2006)$.

93. Open Access Same-Time Information System (Formerly Real-Time Information Networks) and Standards of Conduct, 61 Fed. Reg. 21,737 (May 10, 1996). 
used for the transmission of electric energy in interstate commerce will be required to create or participate in an OASIS that will provide open access transmission customers and potential open access transmission customers with information, provided by electronic means, about available transmission capacity, prices, and other information that will enable them to obtain open access non-discriminatory transmission service. ${ }^{94}$

OASIS has proven a great success. The participation through ISO/RTO operations has contributed greatly to its success.

A look at any of the ISO/RTO websites will show easy access to pricing and service information. Readily available price and other market information are necessary for the adequate function of the complex and immediate electricity market. Electronic capacity is also key to collaborative governance. It fosters broad stakeholder involvement as well as effective market monitoring. While there is still some information asymmetry, it has been largely eliminated in ISO/RTO regimes. Moreover, ISO/RTO implementation makes enforcement of transparency requirements more effective and efficient.

\section{F. Reliability and Long-Term Planning}

Reliability and supply security are consistently at the forefront of industry design in both the EU and the U.S. systems. These problems must be and have been attacked in a variety of ways. Organizational design is one of these. The market approach and the competition it engenders make long-term capital investment risky. Few are willing to speculate on loads that might appear some distance in the future. Coordinated long-term facility planning always creates a dangerous potential for collusion and discrimination. On the other hand, central government planning presents its own dangers. As noted Harvard economist William Hogan observed,

Mandated investments not supported by market signals reveal or create requirements for expanding the scope of central planning and regulatory rather than market decisions. [Because all] investments change the economics of all other investments; mandated investments tend to reinforce the distortions in price signals; the regulatory cure could be worse than the market disease.

Among other things, an organizational design must be found that will plan without compromising the market. Again, collaborative governance seems to have proven to be the best foundation for that design. Because the grids are necessarily interconnected, security and reliability are national or

94. Id. (emphasis added).

95. William W. Hogan, Electricity Market Hybrids: MiXed Market Design, AND INVESTMENT http://ksghome.harvard.edu/ whogan/Hogan_AEEE_011708.pdf.

$21 \quad$ (2008),


at least multistate problems. The larger and more multifaceted ISO/RTOs can afford both to engage in long-term planning and carry forward the results of those plans. For example, the ISO-centered Argentine Approach has proven very successful in generating transmission investment. ${ }^{96}$ An ISO/RTO also has the scope to better protect its customers from immediate breakdowns. For example, PJM was able to stop at the boundaries of its grid the great Midwestern blackout a few years ago. Interestingly, the breakdown stopped not at a state border but at the grid-management border.

Collaborative governance has had further impact on supply security in the United States. The North American Energy Reliability Corporation (NERC) is another private governmental-type entity that has become an effective planning and load security mechanism. ${ }^{97}$ NERC evolved from a voluntary organization among industry members, began in the early 1960 s as the industry's effort to assure reliability among interconnected transmission systems in North America. NERC describes itself as, "an international, independent, self-regulatory, not-for-profit organization, whose mission is to improve the reliability and security of the bulk power system in the United States, Canada and part of Mexico." 98 It oversees reliability for a bulk power system for 334 million people, 830 gigawatts, $340,000 \mathrm{~km}$ long and $\$ 1$ trillion dollars (U.S.) assets. Restructuring naturally brought a distrust of an industry-dominated organization and hence NERC began to insulate itself. In 2006, FERC certified NERC as the "electricity reliability organization" for the United States and an agreement was reached with the Canadian industry and reliability organization. ${ }^{99}$ It now fits even more perfectly into the collaborative governance model.

The EPAct gave FERC new powers to oversee mandatory reliability standards governing the nation's electricity grid. In order to carry out this responsibility, FERC certified an Electric Reliability Organization (ERO) and established the procedures for the establishment, approval, and enforcement of mandatory reliability standards. ${ }^{100}$ The Commissionapproved mandatory standards will rely heavily on NERC standards. ${ }^{101}$ The

96. Id. at 22 (quoting findings that "over the period 1993-2003 ... transmission capacity limits increased by 105 per cent, more than sufficient to meet the increase in system demand of over 50 per cent."). Stephen C. Littlechild \& Carlos J. Skerk, "Regulation of Transmission Expansion in Argentina Part I: State Ownership, Reform and the Fourth Line," CMI EP 61 2004, at 56.

97. North American Energy Reliability Corporation, http://www.nerc.com/

98. NERC, "Fast Facts," http://www.nerc.com/about/fast_facts.html.

99. The original organization became the National Electricity Reliability Council in 1968 and then the North American Electricity Reliability Council in 1981 and the current "Corporation" in 2007.

100. 16 U.S.C. $\$ 824 o(2006)$.

101. Federal Energy Regulatory Commission Staff's Preliminary Assessment of the 
Act charges FERC to reform transmission pricing so as to promote investment in electricity infrastructure. ${ }^{102}$

Bulk transmission reliability faces political barriers that must be mentioned even though they are beyond the scope of this piece. The EPAct delegated new federal "siting" powers to FERC and the Department of Energy (DOE). ${ }^{103}$ It charges DOE to periodically study transmission congestion and designated, if necessary, National Interest Electric Transmission Corridors (NIETCs). ${ }^{104}$ These powers will bring the federal government in direct conflict with state and local authorities. ${ }^{105}$ It is likely that ISO/RTOs will have the local contacts that will ease the tensions for those within their jurisdiction.

Throughout the various EU legislative and administrative stages, concern for the adequacy of electricity supply is apparent. Both the Treaty of Lisbon ${ }^{106}$ and the third package focus on this problem. While the collaborative governance model may well provide the best organizational design, many other elements must be put in place to solve these problems in Europe as in the United States. These other elements are beyond the scope of this piece. It is within the spirit of this discussion, however, to observe that nowhere is a transatlantic (and/or global) dialogue more necessary.

\section{G. Industry-and Market-Participant-Driven Collaborative Governance Creates Motivations Toward Conservation and Alternative Fuels}

An efficient market optimizes the allocation of scarce resources. In the United States, "demand response" programs by RTO/ISO are lowering the demand for electricity. Their networks enable real-time balance of generation and delivery, and this technology replaces some generation. A

North American Electricity Reliability Council's Proposed Mandatory Reliability Standards, http://www. ferc.gov/legal/staff-reports/05-11-06-nerc-assessment.pdf\#xml=http://search.ato $\mathrm{mz} . \mathrm{com} / \mathrm{search} /$ pdfhelper.tk?sp_o $=10,100000,0$.

102. However, pricing in order to benefit investment in bulktransmission facilities presents serious problems. Indeed, that is why a simple market approach has not emerged.

103. Among other things, the Energy Policy Act of 2005 (EPAct), Pub. L. No. 109-58, 119 Stat. 594, amending the FPA, 16 U.S.C. \$ 824p.

104. FERC has adopted rules for filing applications for transmission construction. DOE has now identified two critical congestions areas: the "Mid-Atlantic NIETC" covers all of New Jersey, Delaware, and D.C., most of New York, Pennsylvania, Maryland, and West Virginia, and substantial portions of northern Virginia and eastern Ohio; the "Southwest NIETC" covers parts of southern California and Arizona.

105. State public utility commissions and other officials testified against the two corridors. E.g., Commonwealth of Virginia, Application for Rehearing of DOE Designation Order, Docket Nos. 2007-OE-01, 2007-OE-02 (Nov. 5, 2007). Largely because of these objections, DOE has ordered rehearing. National Interest Electric Transmission Corridor Designation Order, 72 Fed. Reg. 69,202 (Dec. 7, 2007).

106. The Treaty of Lisbon would add TFEU section 176A, which is intended, among other things, to "ensure security of energy supply in the Union." $176 \mathrm{Al}$ (b). 
recently released study, Harnessing the Power of Demand: How ISOs and RTOs Are Integrating Demand Response into Wholesale Electricity Market, shows the savings in electricity resources created by coordinated grid management. ${ }^{107}$ It notes that the ten American grid operators, which serve two-thirds of U.S. customers, facilitate demand-response solutions by conservation in place of hard assets. They allow special design and load manipulation that may handle between $5 \%$ and $15 \%$ of peak load, reducing the need for additional generation and decreasing transmission congestion. ${ }^{108}$ The devices for this demand response are varied and while demand-response alternatives may not necessarily be linked to the regional grid organizations, such organizations have obvious advantages in implementing them.

ISO/RTOs also facilitate the development and utilization of renewables and alternative fuels. ${ }^{109}$ Renewable power sources have their own adverse impacts and tend to be regionally feasible, intermittent, and seasonal. Wind power in the United States is most efficiently generated on the western prairie (where there are few consumers) or the coasts (where there are scenic pollution problems). Solar power also has inherent locational difficulties. Hydoelectric power not only destroys environments but is subject to climate variations. The large integrated grid facilitates a technology and geographic mix that optimizes alternative generation and mitigates their disadvantages.

\section{H. Collaborative Governance and "Third Countries"}

The U.S. model seems to facilitate combination with contiguous nations as well as U.S. states. As the DOE's "Grid Study" observed, the North

107. ISO/RTO COUNCIL, HARNESSING THE POWER OF DEMAND: How ISOS AND RTOS ARE INTEgRating DEMAND RESPONSE INTO WholeSAle EleCtricity MARKeTS (2007), http://www.isorto.org/atf/cf/\%7B5B4E85C6-7EAC-40A0-8DC3-003829518EBD\%7D/IRC DDR_Report_101607.pdf; see also STAFF REPORT, DEMAND RESPONSE AND ADVANCED METERING, at i, http://www.ferc.gov/legal/staff-reports/09-07-demand-response.pdf. ("Estimates of demand reductions in Regional Transmission Organization (RTO) and Independent System Operator (ISO) regions with organized wholesale markets lowered system peaks between 1.4 and 4.1 percent on these peak days. These demand reductions result from a combination of RTO/ISO demand response programs, utility retail demand response, and voluntary customer demand reductions.").

108. Unless instant adjustments can be made in demand, assets must equal peak load. See Peter Fox-PenNer, Electricity Utility Restructuring: A Guide to The Competive ERA 53 (1997) ("To meet the essential condition that total generation instantly equals total load, the power system in a given area must have a capacity as large as the highest moment of total use, or peak demand.").

109. ISO/RTO COUNCIL, INCREASING DEMAND RESPONSE AND RENEWABLE RESOURCES: How ISOs and RTOs Are Helping Meet Important Public Policy ObJectives (2007), http://www.isorto.org/atf/cf/\%7B5B4E85C6-7EAC-40A0-8DC3-003829518EBD\%7D/IRC _Demand_Renewables_Glossy.pdf. 
American grid includes "the borders of Mexico and Canada." ${ }^{10}$ Similarly, NERC describes itself as, "an international, independent, self-regulatory, not-for-profit organization, whose mission is to improve the reliability and security of the bulk power system in the United States, Canada and part of Mexico."111 Again, these cross-national borders' interconnections are voluntary and driven by technical and economic realities when they are not impeded by political borders. Perhaps the inclusiveness in the governance process makes this more palatable.

The U.S. industry successfully joined regions of the Canadian industry in cross-border collaborative governance. Alberta and Ontario have their system operator, but Manitoba is within the Midwest ISO along with a number of U.S. states. ${ }^{112}$ In fact, this formal joint-organization membership understates the coordination between the United States and Canada. Much of this cooperation is conducted by ISO/RTOs in both countries. Indeed, the regional organization greatly facilitates this cooperation. While electricity crosses the border between the United States and Mexico, the arrangements seem less transparent.

In the United States, practicality compelled joint efforts in advancement of organizational accommodates. The same forces seem at work in Europe. For example, in the winter of 2008, France announced its intention to form a "Mediterranean Union." As the Mediterranean Electricity Ring map in the Final Report on the Implementation of TEN-E projects shows ${ }^{113}$ in electricity that union is well underway. Exchange among contiguous national industries seems irresistible.

The Green Paper recognized that the European Union, as all of us, must see its energy task in a global and certainly neighborly perspective. ${ }^{115}$ On the other hand, the Internal Market Proposal provides that "[the] commission proposes a requirement that third country individuals and countries cannot acquire control over a Community transmission system or transmission system operator unless this is permitted by an agreement between the EU and the third country." 116 Relevant to this paper, the Commission also offers, "It may ultimately help to create supra-national transmission operators as the operators are no longer held back by mutual

110. Grid Study, supra note 77, at 2-3 (emphasis added).

111. NERC "Fast Facts," supra note 98 (emphases added).

112. Midwest ISO, http://www.midwestiso.org/page/About\%20Us.

113. Final Report, Implementation of TEN-E projects (2004-2006): Evaluation and Analysis, fig. 10, available at http://ec.europa.eu/energy/infrastructure/studies/doc/2007_11_ten_e_evaluation.pdf (figure 10 is located on page 61 of the report).

115. Electricity Green Paper, supra note 3, at 19-20 (concrete proposal 6).

116. Internal Market Proposal, supra note 3 , at 7. 
mistrust." 117 The U.S. experience with North American ISO/RTOs suggests a model that will indeed enhance trust in a transnational industry. Ownership dilemma may be lessened if the operation of the grids within the European Union are managed by a transparent and inclusive collaborative governance organization.

117. Id. at 7 . 